\title{
MODELLING THE IMPACT OF URBANIZATION ON GROUNDWATER USING SYSTEM DYNAMIC TECHNIQUE. A CASE STUDY OF ARUSHA MUNICIPAL WELL FIELD IN NORTHEASTERN TANZANIA.
}

\author{
Nimzihirwa Kashimbiri ${ }^{1}$, Felix Mtalo², Fredrick Mwanuzi², Nepal C. Mondal ${ }^{3}$, Vijay S. Singh ${ }^{3}$ \\ ${ }^{1}$ Arusha Technical College, P.O. Box 296, Arusha. Tanzania. \\ ${ }^{2}$ University of Dar es Salaam. Water Resources Engineering Department. P.O.Box 35131.Dar es Salaam. \\ Tanzania. \\ ${ }^{3}$ National Geophysical Research Institute (NGRI). Groundwater Section. 500007. Hyderabad. \\ Andhrapradesh. India. \\ E-mail: Nimzihirwa Kashimbiri, E-mail: k_neema@yahoo.com
}

\begin{abstract}
This paper is concerned with the impact of urbanization in aquifer well-system located in the Municipal area of Arusha city, Tanzania. A system dynamic (SD) model was built under VENSIM PLE workbench from twenty-five years (1978-2003) physical and non-physical data to simulate their interactions and relations. This involved use of mathematics ideas and concepts in studying the physical and non - physical components separately, and finally putting them together in new form (model) and study their relations. After model was found to be structurally complete and simulate properly by using the model and unit check tool of VENSIMPLE, parametric calibration of the model follows. Model output results were then compared with existing field conditions and information's with the help of Excel spreadsheet. Historical data of population, rainfall, GDP, aquifer characteristics and land use was used as inputs. The model was trained for data series of 1978 to 1990 and examined for data series of 1990 to 2003. Model efficiency criteria R2, suggested by Nash and Sutcliffe (1970), produced good results ranging from 0.6333 to 0.9868 during calibration and 0.9833 to 0.9985 during verification. The model reveals that urbanization has enormous impact on population which was increasing at a rate of 4\% from 1978 to 2003, which in turn caused increase in water demand for about 6\% annually; as a result aquifer well-system was overstressed due to over-pumping. Lastly a prediction of the situation for 2025 was carried out in succession, and then interpretations and discussion concludes the paper.
\end{abstract}

Key words: Groundwater Resources, Urbanization, Population, System Dynamic, VENSIM PLE, Arusha Municipality, Tanzania

\section{INTRODUCTION}

\section{BACKGROUND OF THE STUDY}

Human being has always settled in areas where there is possibility to get water, practically only there. The existence of populous ancient civilizations is linked to the presence of large rivers (Katiko, 1984); likewise, increased population and activities in many cities today apart from availability of high quality services like good shelter, health facilities, road and transport plus education; their existence are supported by availability of water services whether natural or manmade. Arusha in particular depends on groundwater to augment the surface water scarcity, but in most

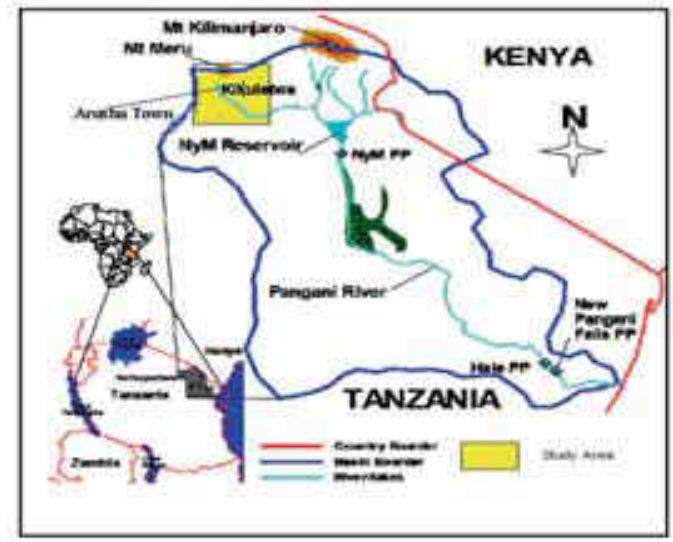

Figure 1: Location Map of Arusha City Study Area Modified from Rohr, P.C., ( 
cases demand exceeds supply as a result excessive utilization renders the service to be significant.

Arusha, located in the Northeastern part of Tanzania near the Mount Meru frontiers (Figure1), covers an area of $93 \mathrm{~km} 2$. In 1961 after Tanzania independence it becomes the center for tourism, business, traders and politics. In 1975 it witnessed remarkable expansion, Orthogonal Frequency Division Multiplex (OFDM). Although OFDM offers attractive performances it has proved not to sustain the noise levels in powerline network and therefore there are still demands to improve the use of OFDM to form a more appropriate modulation scheme in power-line. In order to improve performance a combination of OFDM with Direct-Sequence Code Division Multiple Access (DS-CDMA) to form Multi-Carrier Code Division Multiple Access (MC-CDMA) was suggested (Yee and Fettweis, 1993; Fazel and Papke, 1993). With MC-CDMA signals were modulated through different conventional (M-PSK) modulations and performance of each measured. It was observed that optimum growth and development activities and changes such as construction of buildings and roads, deforestation and many other anthropogenic activities, which sacrificed fertile lands such as Themi Coffee and Sisal Estates, which was converted into industrial and residential area. This has resulted in modification on land use and land cover as well as increased demand for land and water

\section{PROBLEM STATEMENT}

Water demand for domestic, agriculture and industrial activities have outpaced the supply from unconfined Arusha aquifer (JBG, et al., 1987). Rivers network crossing the town have turned to be perennial streams. Previously, before 1977 the town and its periphery were relying mainly on gravity water tapped from natural springs, which was found to be sufficient to take care of the then population of 85,553 inhabitants and few factories and industries (JBG, et al., 1987, WSPA, 1996, Kashimbiri, 2009). Only recently remarkable development of groundwater extractions has been manifested, which was accompanied by an alarming significant lowering of the hydraulic head, drying of stream as well as unexpected water and muddy flood following a short rainfall. It is believed that the main cause is due to increasing population. To justify and manage this behavioural extreme change it is of necessity to assess the situation of aquifer serving the Arusha community in its totality. In this publication a simple assessment integrating Aquifer Drawdown; Population Increase; Rainfall, Runoff and Recharge, Forest and Economy were separately analysed and combined under SD models to assist in decision making involving mult-sectored variations.

\section{DESCRIPTION OF THE STUDY AREA}

\section{General}

Arusha Municipality is located in the Northern part of Tanzania at latitudes $3^{\circ} 24 \gamma \mathrm{S}$ and $3^{\circ} 18 \gamma \mathrm{S}$ of the equator and longitudes $36^{\circ} 39 \gamma_{\mathrm{E}}$ and $36^{\circ} 44 \gamma_{\mathrm{E}}$ of Greenwich Meridian. Its altitude is about $1300 \mathrm{~m}$ a.m.s.l on the southern foot slopes of an ancient volcano namely Mount Meru (4565m a.m.s.1 ). Its population as of 2003 census was over 282,712 inhabitants with a growth rate of $3.8 \%$ per annum on an area of about $93 \mathrm{sq} \mathrm{km}$. (www.tanzania.go.tz/ census/arusha.htm,2003). An extra 60,000 people are estimated to come into the town every day for business and other activities making an estimated population of about 345,000 during the day. With this trend it is expected that by year 2015 there will be over 452,632 inhabitants assuming net migration. Secondly, as industries and other water demanding activities are increasing current source of water will not equal the demand.

Arusha Municipality is supplied with water from three different sources namely, springs boreholes and rivers, the spring sources include OleshaMasama springs along Themi River located $4 \mathrm{~km}$ north of the Municipality and Ngarendolu Springs Located within the Municipality. There are 13 deep wells (boreholes) located in the northern part of the Municipality in Arumeru district and two boreholes located one within the Municipality area and the other near Nduruma River along Moshi Arusha Highway in Arumeru district. Boreholes contribute nearly half of the daily water production whereas the springs and river the other half. The production capacity fluctuates seasonally from an average of $27,000 \mathrm{~m}^{3} /$ day in dry season to $44,000 \mathrm{~m}^{3} /$ day during the rainy season. The daily demand by year 2008 is estimated to the tune of $56,707 \mathrm{~m}^{3} /$ day (WSPA, 1996). This point to the fact that additional sources are required, to maintain adequate supply during dry seasons or incase of failure of rains as it happened recently (Arusha Region Water Master Plan, 2000). 


\section{Topography, Geomorphology and Drainage}

This consists of gently slopping terrain dissected by the valleys of rivers Themi, Naura, and Ngarenarok, Kijenge and Goliondoi which all converge to join Themi in the south. They generally run in the NorthSouth and South-East direction from slopes of Mount Meru towards Shambarai Swamp and the Kikuletwa river where they joins with rivers from Mount Kilimanjaro on their way to Indian Ocean through Nyumba ya Mungu Dam.

Other features include two springs, which are the major collection points of spring water: Ngarenaro Spring located in the town center and Olgilai Spring at the northeast boundaries.

The soil in this area are composed of clayey of recent sediments and weathered mantling ash. The characteristic for the southwestern part of Arusha is extremely extensive black cotton soils, which during the dry season is shrinking leaving cracks on and in the ground surface of up to $50 \mathrm{~mm}$ wide and 1.5m deep (Ongor, 2000; Arusha Urban and Water Sewarage Engineering, 1990).

Vegetation of this area vary spatially from natural to manmade, whereby the southern Maasai steppe are largely bushed grassland and wooded or forested on occasional ranges of hills and mountains. Elevated northern areas are either forested or wooded with few open steep grasslands. The middle medium elevated area is largely cultivated towards the north where it is covered with bushy grasslands and built towards the south. The middle reach of the area is built and overpopulated. Over $95 \%$ of the population depends on land resources for survival (Ntembeleha, 2000). Nevertheless building works, animal husbandry, and wildlife are threatening the agricultural activities. This has necessitated migration and encroachment of agricultural and animal grazing activities into the slopes of Mount Meru. This creates not only conflict between the people but also cause land degradation, erosion, river cessation, destruction of recharge area for groundwater, drying of spring sources and contamination of both surface and groundwater.

\section{Climate}

Climatically, the area belongs to temperate category, with normal rainfall ranging from $738 \mathrm{~mm}$ in the south and $2500 \mathrm{~mm}$ at the summit of Mount Meru.
Annual average for the study area based on five stations is about $1550 \mathrm{~mm}$ (Figure 2). This might have been influenced by Mount Meru and Maasai steppe towards Indian Ocean as Arusha is close to the equator (at lat. 3020ĐS). About $75 \%$ of annual rainfall occurs during March to May season and the remaining from September to November. The latter seems to be the most important rainfall as it bridges the rain gap of June to February. Average evapotranspiration is about $385 \mathrm{~mm}$ per annual.The mean annual temperature is about $20^{\circ} \mathrm{C}$ with the absolute maximum and minimum temperatures of $33^{\circ} \mathrm{C}$ in February and $4^{\circ} \mathrm{C}$ in October respectively. The hottest month is March with an average of $21^{\circ} \mathrm{C}$ and coolest month is July with an average temperature of $17^{\circ} \mathrm{C}$. High rate of evaporation rates of 7.6 to $8.5 \mathrm{~mm}$ per day has been registered in October and November corresponding to high temperatures, radiation and strong winds. During this time there is little or no any recharge to the ground (Ong'or, 2007,2000).

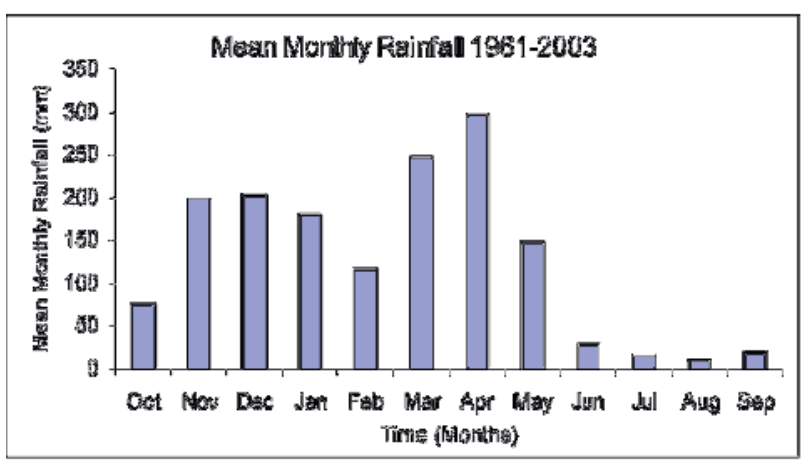

Figure 2: Seasonal Rainfall Regime at Olmotonyi Fortst Station $(09336000)$

\section{Geological and Hydrogeological Setting}

The geology is in volcanic area consisting of igneous rocks, which was formed when magma cooled and solidified (crystallized), which occurs either beneath or on the surface. The Mount Meru a stratovolcano built of both pyroclastic and lava material is one of the 20 volcanoes in the eastern part of the Great Rift Valley, stretching $6400 \mathrm{~km}$ from Jordan to Mozambique. Mount Meru stratovolcano has a symmetrical structure and its volcanic activity is very violent. Lava varies from thin to thick intrusive domes. Inside the main cone is a caldera (basinshaped volcanic depression) of $3.5 \mathrm{~km}$ in diameter (VolcanoWorld, 2005; Johansson and Nilsson, 2003). 
The urban area of Arusha and part of Arumeru district is composed of Neogene volcanic rocks and sediments derived from decomposed weathered volcanic rocks. The main eruption centre for volcanic rocks Mount Meru is made up of alternative layers of basalts, volcanic ashes and tuffs. Materials eroded from ash beds, agglomerates, tuffs and occasional lava flows were washed down the slopes of Mount Meru as mud and debris forming a low gradient apron around the base of the mountain consisting of boulders, pebbles, cobbles and gravel in matrix of clay (Temba, 2004, Johansson and Nilsson, 2003; JBG et al., 1987).

On parts where lava cooled on the surface there is extrusive (commonly of basaltic origin) or volcanic igneous rocks of igneous rocks. Generally the area geology varies mainly between volcanic ash, sand and basalt (Temba, 2004). Area towards Mount Meru north of Arusha town contains a basement depression possibly formed during volcanic activities. The basin could have partly shaped by tectonic movements. Stratigraphy and layers thickness vary considerably over short distances while, the deepest portions of the basin contains a thick layer of fine sand and clay with features of sand and gravel, above it is a thick fluvial volcanic sequence of sand, gravel and volcanic ash, intersected by basaltic layers (JBG et al., 1987).

\section{Hydrogeology}

Tarbuck and Lutgens (2002) reported that the flow (movement) rate and the storage amount of groundwater depend on the subsurface materials porosity and permeability, which can measure a material's capacity of yielding groundwater (Table 1). Porosity is the percentage of the total volume of rock or sediment that are made up of voids or openings. Voids can be spaces between sedimentary particles, joints, faults, cavities and vesicles (voids created when gases left lava). Permeability is the ability of material to transmit a fluid. Different porosity characteristics occur when extrusive rocks cools and solidifies rapidly on the surface. Porosity of basalt ranges from $1 \%$ to $2 \%$ because it is formed from magma of low gas content. Tuffs can have porosity of $14 \%$ to $40 \%$, recent volcanic ash $50 \%$, weathered volcanic deposit can exceed $60 \%$ and pyroclastic material can have high porosities, which is formed by molten volcanic material thrown into the air (Fetter,
2001). According to Tarbuck and Lutgens (2002), the hydraulic characteristics of volcanic rocks depend on chemical composition, mineralogy, volatile content, temperature and mode of extrusion.

Table 1: Porosity, Specific Yield and Specific Retention For Some Geological Materials in Arusha Well field (Tarbuck and Lutgens, 2002).

\begin{tabular}{|l|l|l|l|}
\hline \multicolumn{1}{|c|}{ Material } & \multicolumn{1}{|c|}{$\begin{array}{c}\text { Porosity } \\
(\%)\end{array}$} & $\begin{array}{c}\text { Specific } \\
\text { Yield (\%) }\end{array}$ & $\begin{array}{c}\text { Specific } \\
\text { Retention (\%) }\end{array}$ \\
\hline Clay & 50 & 2 & 48 \\
\hline Sand & 25 & 22 & 3 \\
\hline Gravel & 20 & 19 & 1 \\
\hline
\end{tabular}

\section{Ecology}

Ecologically the area has diversified organisms, animals and vegetations. Availability of water may be the likely factor regulating their co-existence and reproduction. Only recently due to water stress the imbalances occurred due to human development activities that required water diversions, abstractions within and the periphery of town. This has caused significant

change in land use pattern and impacts on the surrounding environmental ecosystem . Coupled with climatic variability a rampant deterioration on biotic and abiotic components of ecosystem is experienced. Overdraft and Groundwater mining are causing most of rivers to go dry shortly after rain season an indication of a likely damage in aquifer. Water maintains natural ecosystems, which sustain biodiversity, help to regulate the hydrological cycle and bring value to people in the form of goods and service derived from activities in these ecosystems. Barth and Hill (2005) pointed out that environmenta sector is an important water user, but often it finds itself at the bottom of the list of priorities when supplies become scarce. It is increasingly being recognized that one of the costs of urbanization is the draining of groundwater or reduced river flows that starve environments of their water. Likewise inflow of municipal wastewater into streams and water bodies' changes water quality and water levels, which in the long run affects aquifer, plant and animals.

Ecological understanding of the complex interactions between human population, environment, economics, political, social/cultural factors is of paramount 
importance for sustainable solution of groundwater quality and quantity in water stressed area . Referring to Falkenmark (1989) water stress occurs when population experience water shortages locally for food production and basic hygiene. Africa Development Bank (ADB,2000) quantified water stress as a situation whereby internal renewable water resources are between 1,000 and 1,667 cubic meters per capita.

Table 2: Population Data ( Source: CIA World Fact Book, 2003)

\begin{tabular}{|l|l|l|l|l|l|l|l|l|}
\hline Year & 1967 & 1978 & 1988 & 1995 & 1996 & 1998 & 2000 & 2002 \\
\hline Population & 46362 & 85553 & 132861 & 179127 & 186785 & 202747 & 220073 & 282712 \\
\hline
\end{tabular}

\section{Population Information's}

According to population census of 2002, Arusha Municipality (Arusha District) consists of 17 Wards and 10 villages and a population of 282,712 people.

The annual growth rate is about $3.8 \%$ slightly higher than the averagenational annual growthrate of $2.091 \%$. Population as of 1967 to 2003 is as indicated in table 2.
The average population density is over 35 per square kilometer, however varies from the central highly populated to the lower plains, which have scattered population. Population growth rates and density in Arusha increased slightly in 1970 s compared to the 1980s. Being one of the of tourist attractions it has become an attractive settlement not only to people from neighboring districts but also to foreigners. In the lowlands, livestock exceed the estimated carrying capacity of 15 livestock units per $\mathrm{km} 2$ and can be one of the major causes of degradation.

Table 3: Gross Domestic Product (TShs and USD)

\begin{tabular}{|c|c|c|c|c|c|c|c|c|c|c|c|c|c|c|c|c|}
\hline Year & 1980 & 1981 & 1982 & 1983 & 1984 & 1985 & 1986 & 1987 & 1988 & 1989 & 1990 & 1991 & 1992 & 1993 & 1994 & 2003 \\
\hline USD & 330 & 385 & 401 & 320 & 248 & 348 & 141 & 122 & 140 & 209 & 218 & 179 & 150 & 168 & 233.1 & 710 \\
\hline
\end{tabular}

\section{Socio-economics Information's}

Goods and services which may include recreation, tourism, water supply, education, administration, protection against disaster (hospital, armed forces etc) and many others; most of these are not traded on commercial markets which makes them to have no direct market value (Monetary terms). In this case GDP (Gross Domestic Product) has been used to represent an approximate economic value of the Arusha Municipality Table 3.

\section{Land Use and Land Cover Changes}

Arusha Municipality is dominantly used as a residential area. For a distance of about $800 \mathrm{~m}$ north of Nairobi-Moshi Road where the well fields are located, the houses are mainly one-storey brick houses and traditional mud houses. Between the houses are plots for cattle's and growing vegetables and fruits. Many petrol stations and car washes exist along Nairobi-Moshi Rd. Shops, restaurants and some lodges are located in the city center. The intensity of housing development decreases further north and the plots get larger. In the north part of the well field the major land use is agriculture and forest.

Roads in this area are unpaved while at the middle reach (city center) roads are paved and buildings are over two storeys. In the city periphery intensity of houses becomes higher with unpaved roads and in the far south population is highly scattered. The far southern part is lowland covered with short grasses typical of Maasai steppe.

Arusha like any other expanding town in Tanzania is facing land degradation, destruction of biological diversity, disturbance of the ecosystem, and threatening water resources (Table 4). Rainfall fluctuations and human interventions, through fire, overgrazing, encroachment, fuel wood, construction 
timber/poles, furniture's wood/timber, creates loss of about $0.5 \%$ of forest and $4.0 \%$ of grass cover annually. Newman and Römberg (1992) and Sandström (1995) reported that woodland and bushland covered $73 \%$ of catchment area in 1960, but only $11 \%$ in 1990 , corresponding figures for cultivated land are $23 \%$ and $58 \%$. Altogether, $81 \%$ of the land area has changed character over the past 30 years.

Table 4: Land Use and Land Cover Areas Rate of Change (Source:Kashimbiri, 2009)

\begin{tabular}{|l|l|l|}
\hline Land Area & Value $(\mathrm{km} 2)$ & Rate of change \\
\hline Watershed & 100 & None \\
\hline Constructed & 30 & $+12.5 \%$ \\
\hline Vegetated & 60 & $-4.5 \%$ \\
\hline Well Field Extent & 20 & None \\
\hline
\end{tabular}

\section{MATERIALS AND METHODOLOGY}

In this paper, model variables (rainfall, stream flows, population GDP and Forest) were individually analyzed to obtain rates of change and pattern which assisted in formulating equations which was required as an input to Vensim PLE (Ventana Simulation Personal Learning Edition-Software) environment for further analysis of their relations and interactions with groundwater variability in Arusha well field aquifer.

\section{Rainfall and River flows Analysis}

Monthly Rainfall data from 1971 to 1993 station no.09336000 (Olmotonyi Forest Rainfall station at $03 \gamma 18^{\prime} 00^{\prime \prime} \mathrm{S}$ latitude \& $36 \gamma^{\prime} 39^{\prime} 00^{\prime} \mathrm{E}$ Longitude) and data from 1927 to 2003 at station no.09336011
(Selian Coffee Estate at $03 \gamma 21^{\prime} 00^{\prime \prime}$ S latitude \& $36 \gamma$ 36’00”E Longitude), and Monthly Flows data from 1DE10 (Themi River at 03 $\gamma_{2}^{\prime} 00^{\prime \prime}$ S Latitude \& $36 \gamma$ 42`00”E Longitude) for 1961 to 1974 in Excel Spread Sheet assisted in extension of rainfall data and flows in a study area, which was not enough for analysis of rainfall pattern and aquifer response. By using linear regression technique (Equation 1\& figure 3) it was possible to extend rainfall at station no. 09336000 from 1971 to 2003 by using data from station no. 09336011. Water Balance Equation(Equation 4) assisted in extension of river flow data at Themi River gauging station No.1DE10 from 23 years to 77 years (Kashimbiri, 2009). With the evaporation data from three stations (Arusha Maji, Arusha Airport and KIA), resulting Rainfall and Flows were then tabulated and used as inputs into a water balance (equation 2) (Moreda and Bauwens, 1997) to extend flows at 1DE10.Finally the rainfall and flow was used in building a system dynamic model under Vensim PLE modeling tool environment for assessment of its link with society and its economy.

$\mathrm{R}_{\text {olmotonyi }}=\beta \mathrm{R}_{\text {selian }}$

Where by: $R_{\text {olmotonyi }}$ is monthly rainfall for a representative recharge area station.

$\mathrm{R}_{\text {selian }}$ is monthly rainfall from a rainfall station with the longest data namely index station.

$\beta$ is a regression coefficient equal to 1.1016

(figure 3) 


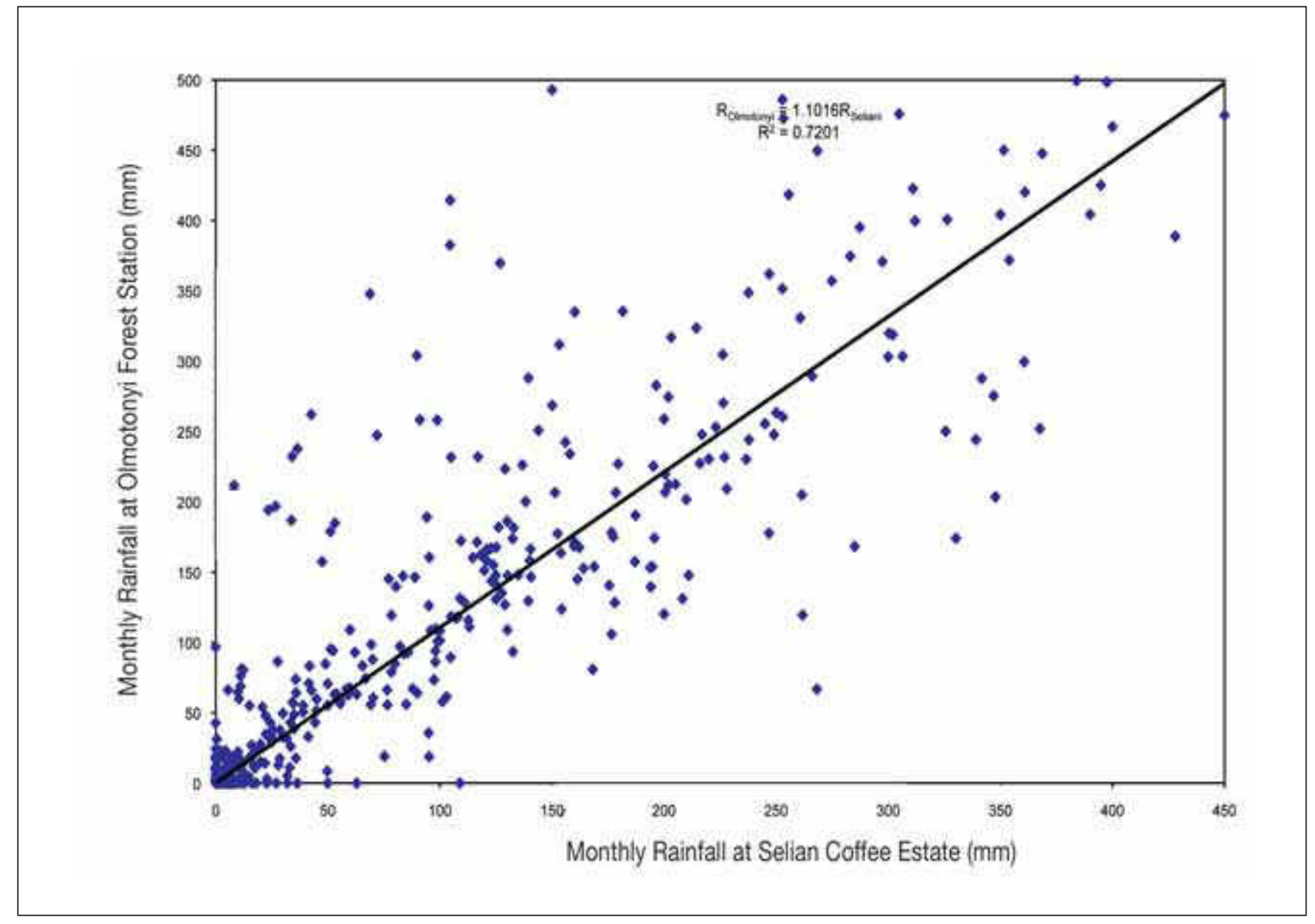

Figure 3: Relationship Between Selian Coffee Estate and Olmotonyi Forest Monthly Rainfall.

Finally, a water balance equation (2) was used to extend stream flows at 1DE10.

$\mathrm{M}_{\mathrm{t}}=\mathrm{M}_{\mathrm{t}-1}+\mathrm{P}_{\mathrm{t}}-\Gamma_{\mathrm{t}}-\mathrm{d}_{\mathrm{t}}$

Where by: $\mathrm{M}_{\mathrm{t}}=$ Soil Moisture Storage $\mathrm{P}_{\mathrm{t}}=$ Precipitation

$\Gamma \mathrm{t}=$ actual evapo-transpiration

$\mathrm{d}_{\mathrm{t}}=$ Stream flows

$\mathrm{t}=$ month

\section{Groundwater Information's}

The aquifer under investigation is basically made up of weathered crystalline basement and volcanic formations and is situated on the southern slopes of Mount Meru; North of Namanga- Moshi Road. Its western point is located $2.1 \mathrm{~km}$ west of Arusha Technical College and the most Eastern location is
$1 \mathrm{~km}$ east of the Mount Meru Hotel. The West-East extent is $6 \mathrm{~km}$. The most north point of exploration is $2.7 \mathrm{~km}$ North of the Namanga Moshi Road (figure 4). The aquifer area is laterally characterized by immediate changes between ashes, sand, tuffs and basalts whereas the sequence is irregular, but vertically there is a succession to be recognized starting from below with ashes, sands, tuffs and basalts.

The average depth, area and volume of aquifer which was required as input in modeling were computed from groundwater levels, well field base, and surface levels by using Surfer Software (Table 5). The software assisted also in contouring using Kriging Method, location of relative position of wells in a well field and estimation of direction of groundwater flows (Figure 4 \&5). 
Table 5: Wells and well field Information's

\begin{tabular}{|c|c|c|c|c|c|c|c|c|}
\hline $\begin{array}{l}\text { Well } \\
\text { No }\end{array}$ & Well Name & $X$ & $\mathrm{Y}$ & $\begin{array}{l}\text { Surface level } \\
\text { a.m.s.l }\end{array}$ & $\begin{array}{c}\text { initial water } \\
\text { table }\end{array}$ & $\begin{array}{l}\text { Aquifer base } \\
\text { (a.m.s.l) }\end{array}$ & $\begin{array}{l}\text { wells capacity } \\
(\mathrm{m} 3 / \mathrm{hr})\end{array}$ & $\begin{array}{l}\text { Discharge } \\
\text { Rate }\end{array}$ \\
\hline 1 & Moivo II & 4264 & 4653.8 & 1437.0 & 1338.0 & 1333.48 & 85 & 31 \\
\hline 2 & Sanawari & 3604 & 4653.9 & 1430.2 & 1370.7 & 1288.68 & 130 & 91 \\
\hline 3 & Moivo I & 4000 & 5653.8 & 1458.7 & 1380.0 & 1325.00 & 80 & 21 \\
\hline 4 & Loruvani New & 4190 & 6264.0 & 1499.9 & 1399.9 & 1295.80 & 100 & 60 \\
\hline 5 & Ilkilorit & 3385 & 5423.0 & 1443.8 & 1399.8 & 1262.28 & 85 & 40 \\
\hline 6 & Ilboru & 3012 & 6000.0 & 1472.8 & 1413.0 & 1330.34 & 185 & 119 \\
\hline 7 & Mianzini & 2346 & 4615.4 & 1437.3 & 1359.0 & 1295.79 & 65 & 43 \\
\hline 8 & Oltulelei & 1808 & 5846.2 & 1472.1 & 1388.1 & 1288.58 & 215 & 164 \\
\hline 9 & Emco & 4050 & 1862.0 & 1335.4 & 1300.0 & 1181.64 & 120 & 44 \\
\hline 10 & Sakina & 385 & 4192.3 & 1410.0 & 1359.9 & 1318.56 & 30 & 26 \\
\hline 11 & Sekei & 4846 & 4615.4 & 1445.0 & 1380.9 & 1289.07 & 20 & 18 \\
\hline 12 & Old Sanawari & 3808 & 5384.6 & 1461.8 & & 1387.91 & 42 & 42 \\
\hline 13 & Loruvani Yard & 3923 & 6384.6 & 1500.0 & 1420.1 & 1378.95 & 30 & 24 \\
\hline 14 & Loruvani Bondeni & 3377 & 6623.0 & 1520.0 & & 1436.00 & 90 & 80 \\
\hline 15 & Kiranyi & 1000 & 6000.0 & 1433.0 & 1383.0 & 1233.00 & 320 & 39 \\
\hline 15 & Ngarendolu Spring & 1886 & 4544.5 & 1394.0 & 1394.0 & 1200.00 & 166 & \\
\hline 16 & Oliglai Spring & 6656 & 5591.4 & 1582.0 & 1582.0 & 1380.00 & 1083 & \\
\hline 17 & ATC & 4000 & 4653.9 & 1430.2 & 1370.7 & 1288.68 & 130 & 91 \\
\hline
\end{tabular}

Usually Transmissivity (T) and Storativity (S) are aquifer parameters required to assess groundwater potential and its management in any area. In this case by using predetermined aquifer porosity (Table 1), computed volume of aquifer by SURFER software (Table 5) and equation 3 we were able to estimate the storage capacity of an aquifer as about $35 \mathrm{~km}^{3}$ of water

$$
V_{i}=n V
$$

where $\mathrm{n}=$ porosity

V $i=$ voids

$\mathrm{V}=$ volume of sample

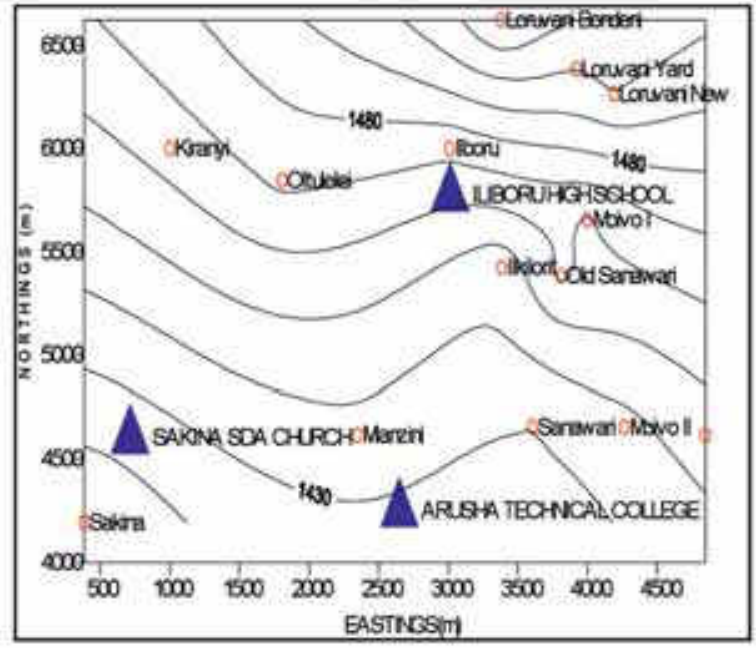

Figure 4. Arusha Contour Map With Relative Position of Wells

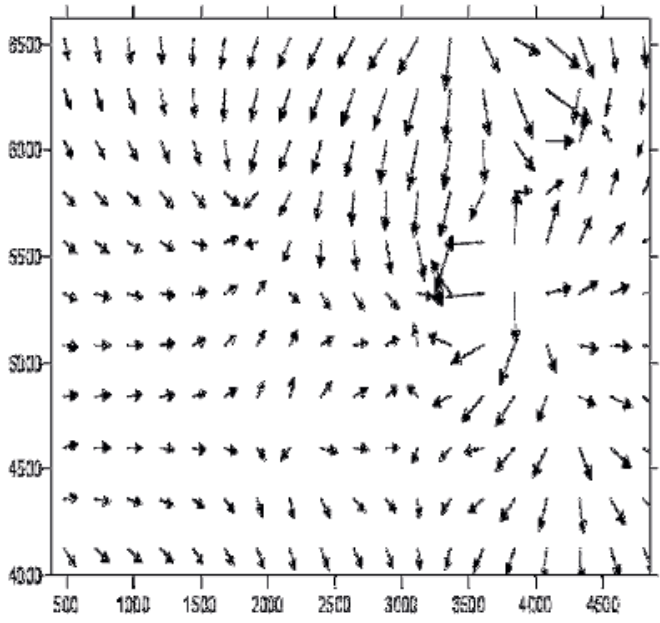

Figure 5: Vector Diagram iodisating Groundwater Flow Direction 
The average value of recharge which is probably the most difficult of all measures in the analysis was computed by modifying empirical relation which was first developed by Chatuverdi in 1973 (Chatuverdi 1973) and modified by Kumar and Seethpathi in 2002 (Kumar et al.,2002). Due to difference in location of study area having different soil properties and aquifer characteristics the following empirical expression was modified from Chatuverdi expression by using regression analysis and used (equation 4 ).

$\mathrm{R}=1.15(\mathrm{P}-80.0)^{0.76}$
The 80.0 value in the Chatuverdi expression was considered from a rainfall of October which showed no direct contribution to the recharge during data collection, but this might be the useful rainfall for the recharge of November to May as it prior wets the drier ground. Kumar pointed out that this value may account for runoff, soil moisture deficit, interception, and evaporation losses (Kumar et al., 2002). It was then estimated that $18.46 \%$ of annual rainfall is contributing to recharge which is about $285.98 \mathrm{~mm}$ annually (Table 6). The annual recharge value was computed by other methods and then related with findings made by other researchers like Ntembeleha, 2000 and Ongor, 2000 that was found to relate (Table 7).

Table 6: Average Annual Monthly Rainfall and Groundwater Recharge (Olmotonyi Forest Rainfall Station -0933600

\begin{tabular}{|l|l|l|l|l|l|l|l|l|l|l|l|l|}
\hline Month & Jan. & Feb. & Mar. & Apr. & May & June & July & Aug. & Sept. & Oct. & Nov. & Dec. \\
\hline $\begin{array}{l}\text { Rainfall } \\
(\mathrm{mm})\end{array}$ & 180.7 & 118.8 & 248.6 & 297.6 & 148.2 & 29.6 & 15.6 & 10.4 & 19.7 & 77.5 & 199.1 & 203.3 \\
\hline $\begin{array}{l}\text { Recharge } \\
(\mathrm{mm})\end{array}$ & 36.74 & 17.71 & 54.19 & 65.78 & 27.24 & 0 & 0 & 0 & 0 & 0 & 41.60 & 42.72 \\
\hline
\end{tabular}

Table 7: Summary of Estimation of Natural Groundwater Recharge in Arusha Well Field

\begin{tabular}{|c|l|l|l|l|}
\hline S.No. & Estimation Technique & $\begin{array}{l}\text { Recharge } \\
\text { Rate } \\
\text { mm/year }\end{array}$ & $\begin{array}{l}\text { Percentage } \\
\text { Rate } \\
\text { of Recharge }\end{array}$ & $\begin{array}{l}\text { Volume } \\
\text { Mm3/year }\end{array}$ \\
\hline 1. & Chatuverdi Empirical (Kashimbiri, 2009) & 285.98 & 18.46 & 6.1 \\
\hline 2. & CRD Method (Kashimbiri, 2009) & 255.94 & 16.52 & 5.4 \\
\hline 3. & CRD Method (Ntembeleha, 2000) & 309.86 & 20.00 & 6.6 \\
\hline 4. & Regression Technique (Kashimbiri, 2009) & 267.10 & 17.24 & 5.8 \\
\hline 5. & JBG Approach (AUWSD,1990) & 207.20 & 13.37 & 4.5 \\
\hline 6. & Numerical Methods (Odero, 1998) & 212.25 & 13.70 & 4.5 \\
\hline 7. & Modflow +ArcViewGIS(Ongor, 2007) & 122.00 & 07.87 & 2.6 \\
\hline
\end{tabular}

\section{System Dynamic Technique}

To take care of diversified interests in a watershed, system dynamic SD is proposed and applied as one of the simple technique using simple tools in assessment of the impacts of population in well field aquifer on areas with inadequate information's experiencing stress in its water resources.
Jeffers (1978) pointed out that system analysis is not a mathematical technique, nor even a group of mathematical techniques. It is a broad research strategy that certainly involves the use of mathematical techniques and concepts, but in a systematic, scientific approach to the solution of complex problems. System Dynamic (SD) models have the major benefit of making explicit all 
assumptions about how things are connected and that it is not a replacement for experimentation and mathematical analysis, but a supplement that allows more insights and understanding at the early stages of skill development and finally on decision. Hence, it provides us with tools for precisely understanding complex man-land systems through a conceptual framework of thought, handling complex interactions (Kashimbiri et al., 2005; Chen et al., 2004 \& Forrester, 1978). This interdependence of elements of the model helps to consider a basin as a system made up of interacting parts rather than isolated parts.

\section{Model Building and Assessment}

VENSIM PLE modeling Software, which uses a workbench toolbox metaphor to deal with models and data, is used in building a SD model for assessment of effect of Urbanization in groundwater resources (Figure 8). The Workbench contains a menu, a model, a variable, datasets, a toolbar, one or more toolsets, controls, tool output windows and model building windows (VENSIM, 2002). In this paper VENSIM PLE a public domain software package which can freely be downloaded from the website http://www. vensim.com/ is not discussed, but used as a tool to achieve the objective where its performance is checked against real world (field) information's Yearly Rainfall, GDP, Population, Stream Flow, and Water Levels data from Arusha watershed was chosen for model assessment which included training (calibration) period 1978 to 1990 and examination (verification) period 1990 to 2003. For model efficiency, criteria suggested by Nash and Sutcliffe (1970) equation 5, has been applied in assessing the accuracy of SD model developed for both training and examination periods.

$$
R^{2}=\left[-\frac{\bullet_{k=1}^{N}\{\text { Qobs }-\hat{Q} e s t\}^{2}}{\bullet_{k=1}^{N}\left\{\text { Qobs }-\bar{Q}_{c a l i b}\right\}}\right] \times 100 \%
$$

Where Qobs are actual observed values

$\hat{Q}$ est are model output values,

$\bar{Q}$ calib are mean values obtained during calibration period

$\mathrm{N}$ is the corresponding number of $\mathrm{Q}$.

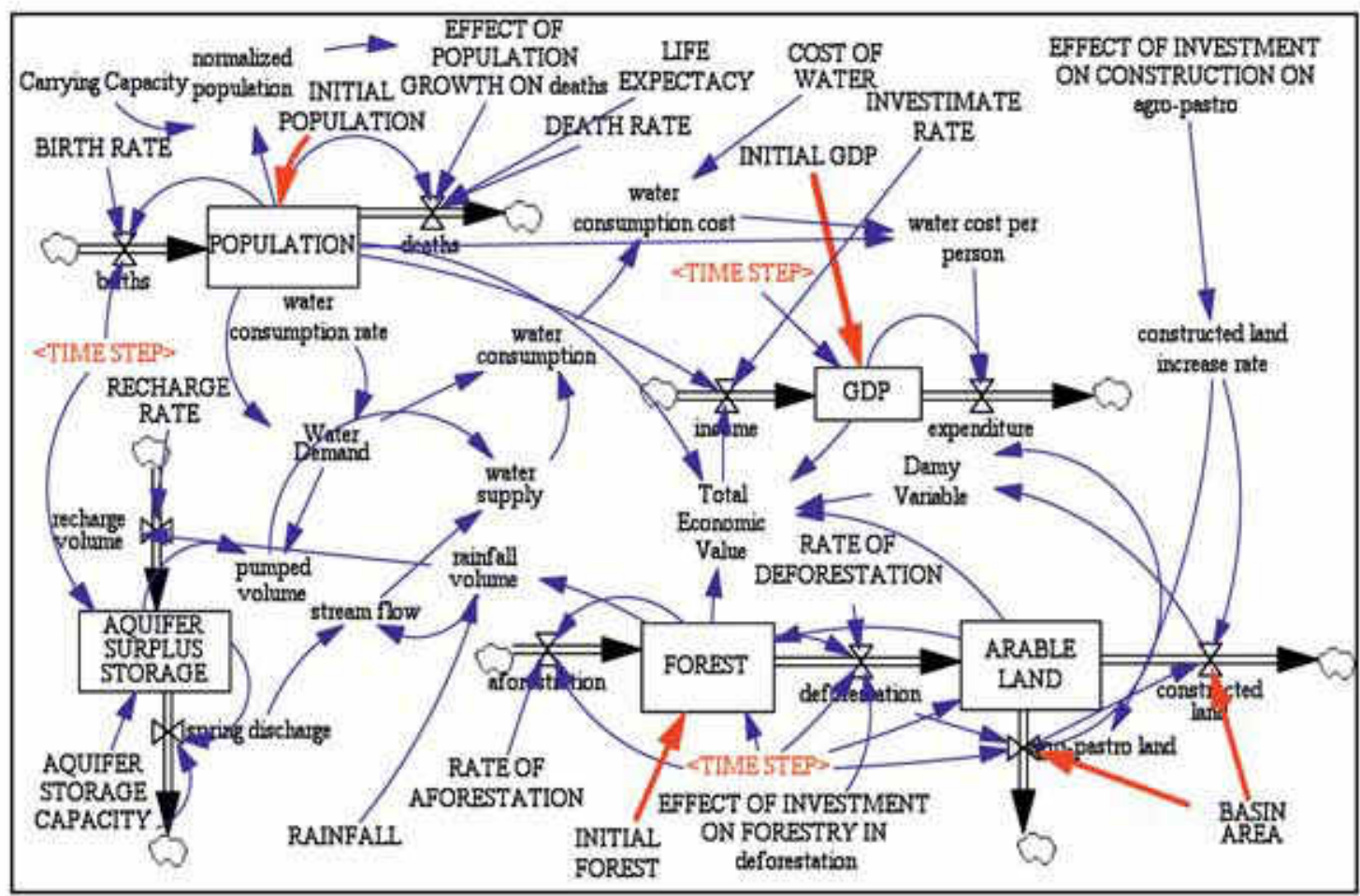

Figure 8: Nature and Society Interaction Model 

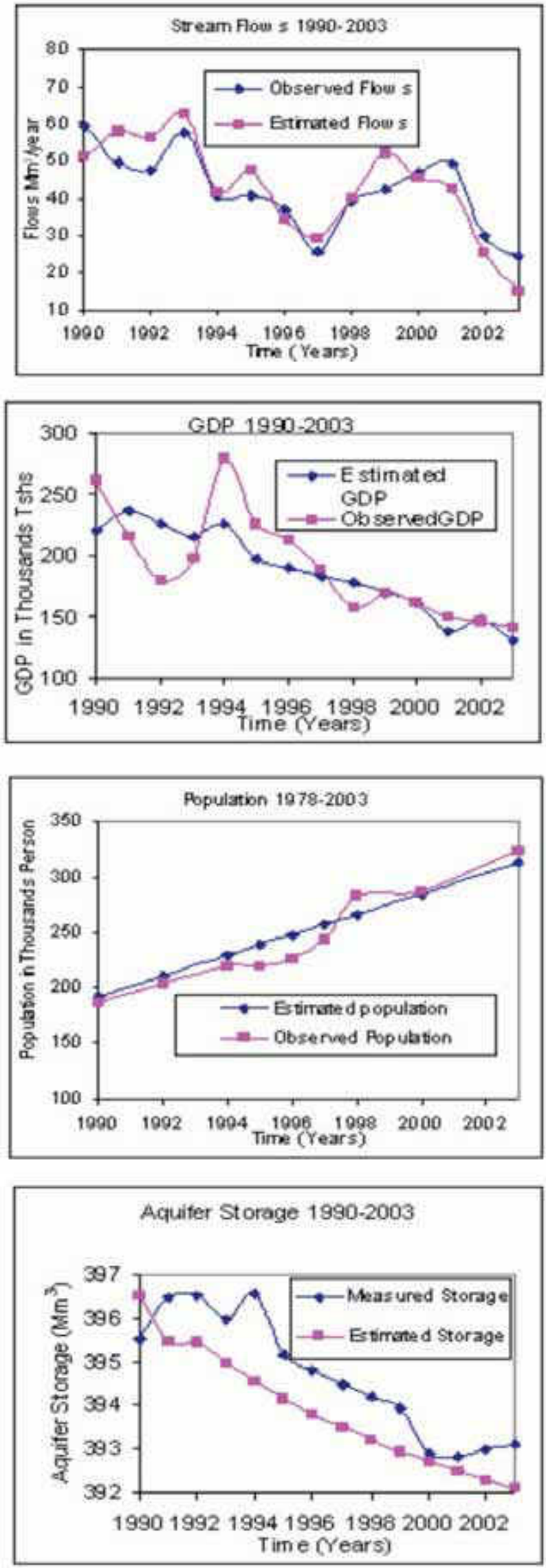

Figure 7: Model Validation Efficiency

1990 - 2003
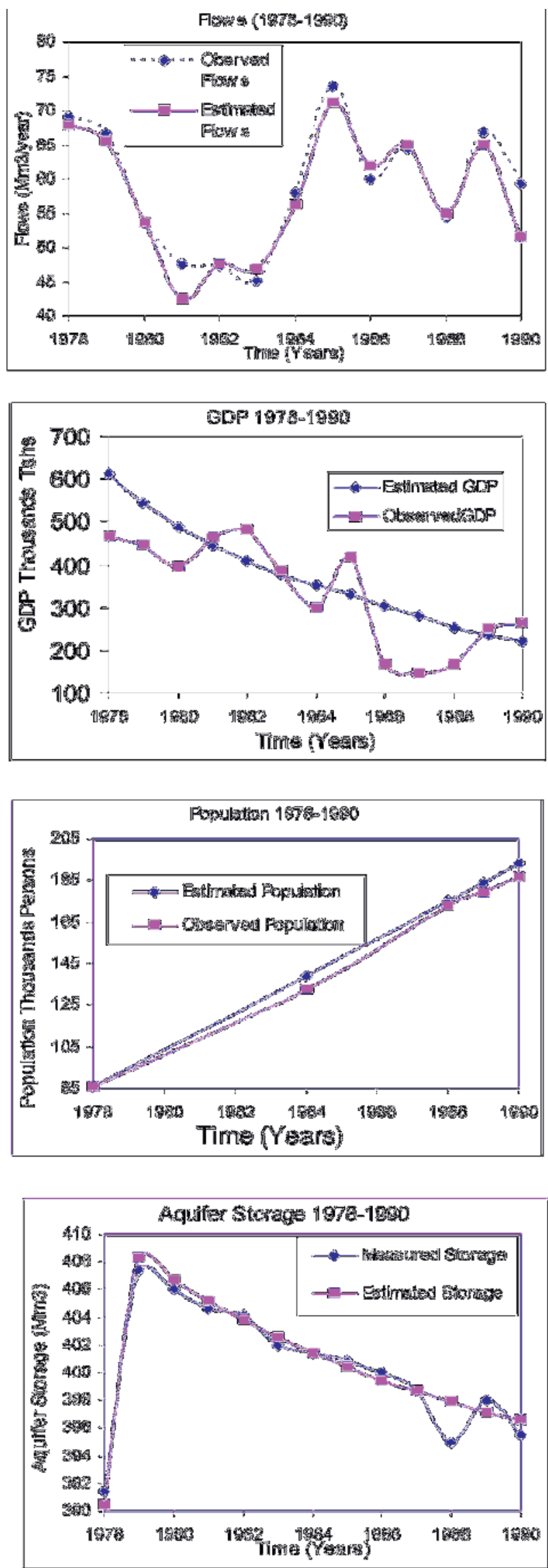

Figure 6: Model Validation Efficiency

1978 - 1990 


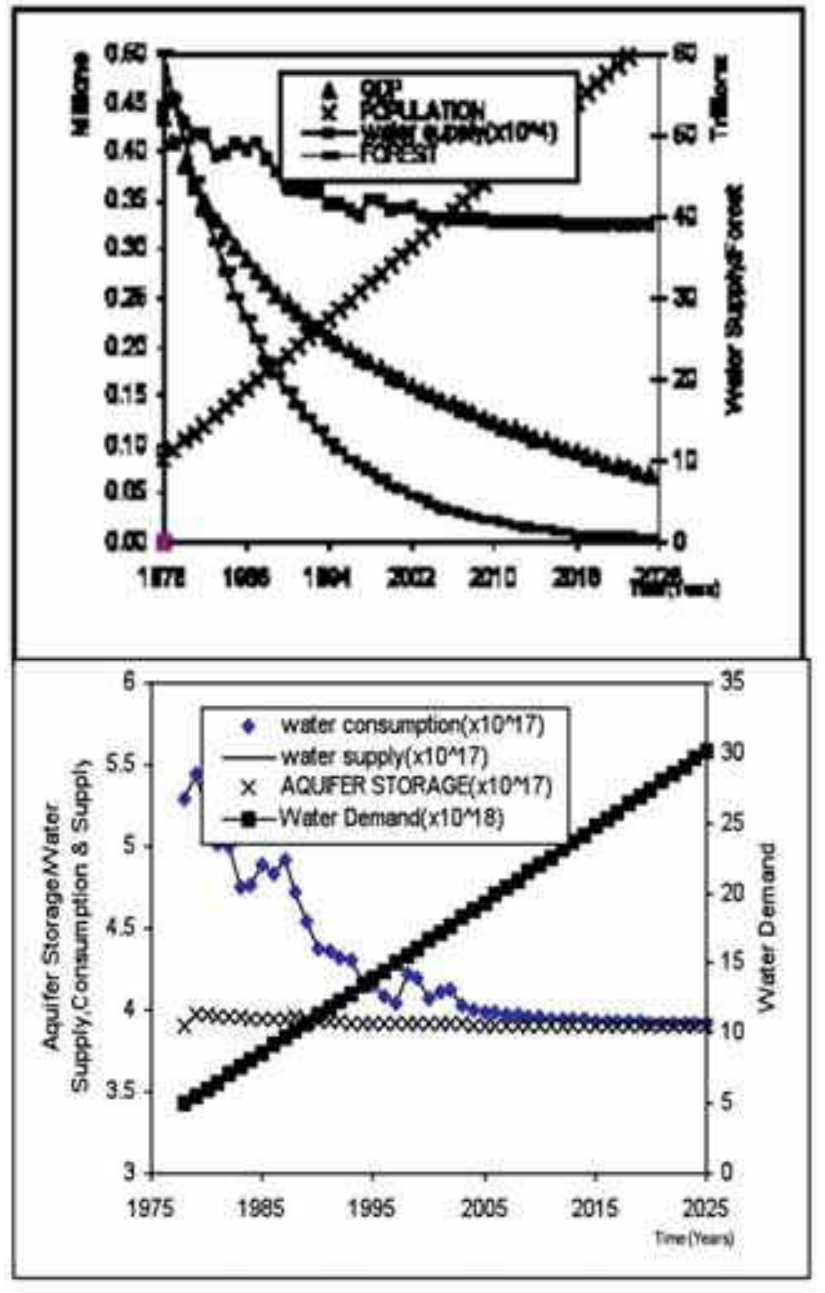

Figure 9: Ecological Relation between Human and Water $\left(\mathrm{mm}^{3}\right)$

\section{RESULTS}

After model was found to be structurally complete and simulates properly by using the model and unit check tool command of VENSIM PLE, calibration of the model followed. Calibration involved finding the values of model Constants that make the model generate behavior curves that best fit the real world data. Then performance of reality check (Validation) followed. The model efficiency R2 (Nash and Sutcliffe, 1970), are as tabulated in table 8.

Figure 9 clearly indicates that urbanization has caused a rampant increase in population from 8,553 persons in 1978 to 309,245 persons in 2002 , which is $3.8 \%$ per year. This obviously caused high demand for water resources and land. However on simulating the model, deaths was found to be increasing more quickly than population, as population was growing to a large size. Probably this may be caused by the fact that higher populations are nearer limit of resources (i.e. water \& food) and therefore on average people die more quickly. At the same time study depicts that rainfall and flow has not changed very much over the years although there is indication of decreased groundwater storage. In one year Arusha Municipality receives a total of $150 \mathrm{Mm}^{3}$ from rain, which is over $96 \%$ of its current domestic demand of $20.7 \mathrm{Mm}^{3}$ per year. But due to uncontrolled human activities and nature of the area only an average of $13 \mathrm{Mm}^{3}$ are available for use, which is less than $37.2 \%$ of the current demand.

Table 8:Model Performance Results

\begin{tabular}{|l|l|l|}
\hline Parameter & $\begin{array}{l}\text { Calibration } \\
1978-1990\end{array}$ & $\begin{array}{l}\text { Verification } \\
1990-2003\end{array}$ \\
\hline Population & 0.9976 & 0.9730 \\
\hline GDP & 0.5770 & 0.5708 \\
\hline Flows & 0.7224 & 0.3820 \\
\hline
\end{tabular}

Likewise, in the first few years of production, the aquifer supply was found to be increasing and there after it started to decrease. This can best be explained by the supply and demand principle, where by at the beginning, pumped (removed) water from the aquifer created space for extra storage, but as time went on and withdrawal exceeded recharge (return to the aquifer was less than what was withdrawn). This can be depicted by river flow cessation and groundwater drawdown.

Therefore the time will be reached where there will be no balance in an aquifer and the replaced air in the pore spaces may damage the aquifer due to compression, since $\rho_{\text {air }}<\rho_{\text {water }} \Leftrightarrow$ Atmospheric Pressure $<$ Hydrostatic Pressure.

\section{CONCLUSIONS}

Although Arusha is stressed, development activities that require water diversions, abstractions and storage are still being carried out at various scales in several parts, within and at its outskirts. This has caused significant change in land use patterns. These changes in turn have significant impacts on the surrounding environment ecosystem. Coupled with climatic variability, these changes may eventually lead to the deterioration of ecosystem. Ecosystem in this context includes biotic (living organisms: human; plants, animals etc) and abiotic (non-living: water) components. 


\section{RECOMMENDATIONS}

It is recommended that Arusha Municipality should start thinking of the means of retaining the rainfall instead of just living the runoff to be wasted. Likewise settlement should be away from the recharge and the well field areas. Currently the Municipal needs about $7 \mathrm{Mm} 3$ extra to meet only its domestic annual demand.

\section{ACKNOWLEDGMENTS}

This publication was made possible after a fellowship award by CSIR-TWAS at NGRI (National Geophysical Research) in India. Appreciation is extended to MHEST (Ministry of Higher Education, Science and Technology) and ATC (Arusha Technical College) -Tanzania, for having awarded me scholarship and study leave to attend Doctorate Degree Course at UDSM (University of Dar es Salaam-Tanzania). Special thanks are to WRED (water Resource Engineering Department-UDSM), DDCA (Drilling and Dam Construction AgencyArusha Branch), and AUWSA (Arusha Urban Water Supply Authority) for allowing me to use their data bank.

\section{REFERENCES}

Arusha Region Water Master Plan, (2000). Groundwater Resources (Hydrogeology). Part III of the Plan: Methods, Data, Analysis and Assessments. Vol. 14. Final Report

Arusha Urban and Water Sewarage Engineering (1990). Drilling Final Report. Arusha, Tanzania.

AUWSD (Arusha Urban Water Supply Department), (1990), Arusha Water Supply Preliminary Report "TV Inspection of Production Boreholes"

Barth, G.R., and Hill, M.C. (2005). Parameter and Observation Importance in Modeling Virus Transport in Saturated Porous Media SystemsInvestigations in a Homogeneous System. Journal of Contaminant hydrology. Vol. 80 Issue 3-4 pp 107-129.

Chatuverdi, R.S. (1973). A Note on The Investigation of Groundwater Resources in
Western Districts of Uttar Pradesh. Annual Report, U.P. Irrigation Research Institute, pp 86-122.

Chen, Y.F., Jie, Qi, Zhou, J.X. (2004). Dynamic Model of Man Land System in Response to Environmental Catastrophe. Human and Ecological Risk Assessment. Volume 10, Number 3, pp 579 - 59 .

CIA World Fact Book (2003), "2002 Population Census Report", Tanzania Files, CIA Publications, Directorate of Intelligence, Washington, D.C. USA

Fetter, C.W. (2001). Applied Hydrogeology (4th Edition). Upper Saddle River: Prentice Hall.

Forrester, J. W., (1978) “Urban Dynamics”, M.I.T. Press.

http://www.volcano.und.nodak/edu/vw.html

JBG Consulting Engineers and GKW Consult (1987). Arusha water Supply Drilling Programme Interim Report. Dar es salaam.

Jeffers, J.N.R. (1978): An Introduction to System Analysis with Ecological Applications. University Park Press, Baltimore, MD, USA.

Johansson, A. and Nilsson, H. (2003). Water Quality Assessment in Arusha Wellfield and Surroundings. (Examensarbete med MFSbidrag) Unpuplished

Kashimbiri, N., Chen, Y.N. and Zhou, J.X. (2005). Assessment of Effects of Human Development on the Environment by Using System Dynamic Modeling Technique (SD): A Case Study of the Mkomazi Watershed (Pangani Basin) in Northeastern Tanzania. Human and Ecological Risk Assessment, Volume 11, Number 2, pp $451-467$.

Kashimbiri, N. (2009). Development of a System Dynamic model for Investigation of Groundwater Variability in Arusha Municipality Well Field. PhD Thesis (Draft), University of Dar Es Salaam, Tanzania. 
Katiko, T.S (ed) (1984). Groundwater Explorations and Assessment in Developing Countries. Workshop Report 28 Nov 1984. Tampere University of Technology.

Kumar, C.P. and Seethapathi, P.V. (2002). Assessment of Natural Groundwater Recharge in Upper Ganga Canal Command Area. Journal of Applied Hydrology, Association of Hydrologists of India, Vol. XV, No.4, October 2002, pp 13-20.

Moreda, F. and Bauwens, W.(1997). Conceptual Monthly water Balance Models Applied to Arid and semi-Arid Catchments. Paper Presented to 5th Scientific Assembly of IAHS in the Workshop on Flow Forecasting Under Conditions of Limited Data (April, 1997 Rabat, Morocco).

Nash,J.E., Sutcliffe, J. (1970). River Flow Forecasting Through Conceptual Models. Part1. A Discussion of Principles. J.Hydrol. 10, pp 282-290.

Newman, P. and Römberg, P. (1992).Changes in Land Utilization within the Last Three Decades in the Babati Area. A Minor Field Study(MFS). Swedish University of Agricultural Sciences, Uppsala, Sweden, Working Paper 198.

Ntembeleha D.A. (2000). Evaluation of Changes in Groundwater Recharge in Arusha Town Basin. MSc (WRE). Dissertation, University of Dare s salaam.

Odero,M.O. (1998), “Seasonal Groundwater Recharge in Arusha Town Basin, Tanzania (Finite Difference Method)", MSc(WRE) Dissertation, University of Dar es salaam

Ong’or, B.T.I., (2000). Groundwater Management of Arusha Aquifer. Tanzania. MSc (WRE). Dissertation, University of Dar es Salaam.

Ong'or, B.T.I., (2007). Groundwater Overdraft Vulnerability and Environmental Impact assessment in Arusha. Environmental Geology, Number 51 pp 1171-1176.

Røhr, P.C.,(2003).A HydrologicalStudy Concerning the Southern Slopes of Mt.
Kilimanjaro, Tanzania. Dr. Ing.-thesis 2003:39. Faculty of Engineering, Science and Technology Department of hydrologic and Environmental Engineering. Norwegian University of Science and Technology.

Sandström ,K.(1995).The Recent Lake Babati Floods in Semi-Arid Tanzania- A response to Changes in Land Cover ?Geografisca Annaler. 77A (1-2):pp 35-44. (Scandinavian University Press om Licence from the Swedish Society for Anthropology and Geography).

Tanzania National Website, (2003). http://www. tanzania.go.tz/census/arusha.htm

Tarbuck, E.J. and Lutgens, F.K. (2002). Earth: An Introduction to Physical Geology 7th ed., Upper Saddle River, New Jersey, PrenticeHall, Inc.

Temba, L.S. (2004). Ministry of Water and Livestock Development Report on Hydrogeological and Geo-Electrical Survey for Locating a Borehole Site for Deep Borehole Drilling for Water Supply to Arusha Municipality in Arusha Region- Tanzania. Report No.R2/Vol.X/12.

USDA (1972). National Engineering Handbook, Section 4, Hydrology. USDA, Soil Conservation Service. US Government Printing Office, Washington, DC.

VENSIM PLE (VENTANA SIMULATION ENVIRONMENT, PERSONAL LEARNING EDITION) 2002), Vensim Product Center, Ventana Systems Inc. URL: http://www. vensim.com. E-Mail: plesupport@vensim. com.

Volcano World, (2005). Website of the University of North Dakota. http://www.volcano.und. nodak/edu/vw.html

Water Supply Program Arusha (1996). Project No. 9570037 Report Phase1 by Consulting Engineers (CES)-Salzgitter GmbH, Salzigtter Bad of Germany; SEBA-Messtechnik, Klagenfurt of Austria and M-Konsult- Dar es Salaam, Tanzania.

Wikipedia URRL (2007). The Great Rift Valley. Http://en.wikipedia.org/EastAfrica. jpg. 